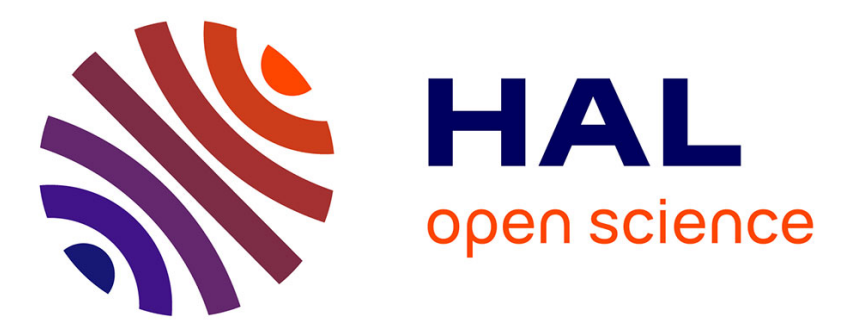

\title{
Induction of ovulation in goldfish, Carassius auratus by pimozide and analogues of LH-RH
}

\author{
M. Sokolowska, R.E. Peter, C.S. Nahorniak, C.H. Pan, J.P. Chang, L.W.
}

Crim, Claudine Weil

\section{- To cite this version:}

M. Sokolowska, R.E. Peter, C.S. Nahorniak, C.H. Pan, J.P. Chang, et al.. Induction of ovulation in goldfish, Carassius auratus by pimozide and analogues of LH-RH. Aquaculture, 1984, 36, pp.71-83. 10.1016/0044-8486(84)90055-3 . hal-02728616

\section{HAL Id: hal-02728616 \\ https://hal.inrae.fr/hal-02728616}

Submitted on 2 Jun 2020

HAL is a multi-disciplinary open access archive for the deposit and dissemination of scientific research documents, whether they are published or not. The documents may come from teaching and research institutions in France or abroad, or from public or private research centers.
L'archive ouverte pluridisciplinaire HAL, est destinée au dépôt et à la diffusion de documents scientifiques de niveau recherche, publiés ou non, émanant des établissements d'enseignement et de recherche français ou étrangers, des laboratoires publics ou privés.

\section{다(1)(2)}

Distributed under a Creative Commons Attribution - ShareAlikel 4.0 International 


\title{
INDUCTION OF OVULATION IN GOLDFISH, CARASSIUS AURATUS, BY PIMOZIDE AND ANALOGUES OF LH-RH
}

\author{
M. SOKOLOWSKA, R.E. PETER, C.S. NAHORNIAK, C.H. PAN, J.P. CHANG,
} L.W. CRIM ${ }^{1}$ and C. WEIL ${ }^{1,2}$

Department of Zoology, University of Alberta, Edmonton, Alta. T6G 2E9 (Canada)

'Marine Sciences Research Laboratory, Memorial University, St. John's, Newfoundland A1C 5S7 (Canada)

${ }^{2}$ Permanent address: Institut National de la Recherche Agronomique, Laboratoire de Physiologie des Poissons, Campus de Rennes-Beaulieu, 35042 Rennes Cedex, France

(Accepted 3 April 1983)

\section{ABSTRACT}

Sokolowska, M., Peter, R.E., Nahorniak, C.S., Pan, C.H., Chang, J.P., Crim, L.W. and Weil, C., 1984. Induction of ovulation in goldfish, Carassius auratus, by pimozide and analogues of LH-RH. Aquaculture, 36: 71-83.

The effects of intraperitoneal injections or pellet implantations of luteinizing hormone-releasing hormone analogues, des-Gly ${ }^{10}-\left[\mathrm{D}-\mathrm{ALA}^{6}\right]-\mathrm{LH}-\mathrm{RH}$-ethylamide (LRH. Aa) or des-Gly ${ }^{10} \cdot\left[\mathrm{D}-\mathrm{Trp}^{6}\right]-\mathrm{LH}-\mathrm{RH}$-ethylamide (LRH-At), respectively, and the combination of these treatments with pimozide, a dopamine antagonist, on serum gonadotropin (GtH) and ovulation in goldfish held at $18-20^{\circ} \mathrm{C}$ were investigated. Injections of LRH-Aa $(0.1 \mu \mathrm{g} / \mathrm{g}$ body weight) or pellet implants of LRH-At ( 25 and $125 \mu \mathrm{g} /$ fish) alone increased serum GtH levels, but were relatively ineffective for inducing ovula* tion in goldfish ( $\cong 25 \%$ rate of occurrence). Pimozide greatly potentiated the GtH release response to LRH-Aa injections or LRH-At pellet implantations. A high rate of occurrence of ovulation ( $87 \%$ ) was observed within $24 \mathrm{~h}$ when pimozide was injected prior to or with the first of two injections of LRH-Aa, or following implantations of LRH-At pellets that give continuous release of LRH-At. These results are consistent with the idea that dopamine acts directly at the pituitary level as a GtH release-inhibitory factor in goldfish.

\section{INTRODUCTION}

It is well established that synthetic luteinizing hormone-releasing hormone (LH-RH) and its "superactive" analogues stimulate gonadotropin (GtH) secretion in teleosts (for review see Peter, 1982, 1983). LH-RH and the analogues D-Ser(But) ${ }^{6} \mathrm{LH}-\mathrm{RH}$-ethylamide and des-Gly ${ }^{10}\left[\mathrm{D}-\mathrm{Ala} \mathrm{a}^{6}\right]$ LH-RH-ethylamide (LRH-Aa) have been shown to be effective, either alone or following a primer injection of salmon GtH, in accelerating the time of oocyte maturation and ovulation of coho salmon (Oncorhynchus 
kisutch) (Donaldson et al., 1981/1982; Van Der Kraak et al., 1983). Crim et al. (1983) reported that intraperitoneal implantation of pellets that give a long-term release of a "superactive" analogue caused a prolonged increase in plasma GtH levels, resulting in acceleration of the time of ovulation of landlocked Atlantic salmon (Salmo salar) by several weeks. Rainbow trout (Salmo gairdneri), and presumably other salmonids, have a relatively gradual increase in blood levels of GtH prior to ovulation, with oocyte maturation occurring over many days (Fostier et al., 1978; Jalabert and Breton, 1980). Coho salmon have increased plasma GtH levels for several days after a single injection of LRH-Aa (Van Der Kraak et al., 1983), which underlies the effectiveness of the analogue in accelerating oocyte maturation and ovulation in this species.

Goldfish (Stacey et al., 1979a) and common carp (Cyprinus carpio) (Fish Reproductive Physiology Research Group and Peptide Hormone Group, 1978) have a marked ovulatory surge of GtH release, lasting about $12 \mathrm{~h}$ in goldfish at $20^{\circ} \mathrm{C}$. To be effective in inducing ovulation in goldfish and carp, $\mathrm{LH}-\mathrm{RH}$ or analogues must stimulate a similar surge of GtH release that lasts at least as long as the endogenous surge. LRH-Aa has been used to induce ovulation in several species of carp in the People's Republic of China (Cooperative Team for Hormonal Application in Pisciculture, 1977; Fukien-Kiangsu-Chekiang-Shanghai Cooperative Group, 1977; Jiang et al., 1980), although the conditions for the successful use of LRH-Aa are not clear from these publications, and the time to ovulation after injection was quite variable. Three daily injections of very large dosages of LH-RH induced ovulation in goldfish (Lam et al., 1975). Although LRH-Aa injections, of relatively low dosages, in mature goldfish at $12^{\circ} \mathrm{C}$ caused a large increase in serum GtH levels lasting at least $24 \mathrm{~h}$ (Peter, 1980), various combinations of timing of injections and dosages of LRH-Aa in mature female goldfish at 12 or $20^{\circ} \mathrm{C}$ have either failed to induce ovulation or caused only a low percentage $(<50 \%)$ of the fish to ovulate (Chang and Peter, 1983b; R. Peter, unpublished data, 1977-1981). Similarly, injections of LRH-Aa in common carp have had limited success in inducing ovulation (Weil et al., 1980; R. Peter, K. Bieniarz, R. Billard, M. Sokolowska and L. Crim, unpublished data, 1981, 1982).

Recently, Chang et al. (1983) and Chang and Peter (1983a) demonstrated that dopamine has GtH release-inhibitory activity in goldfish to modulate spontaneous release of $\mathrm{GtH}$, and to directly block or modulate the action of GtH-releasing hormone. Furthermore, Chang and Peter (1983b) found that pimozide, a dopamine antagonist, greatly potentiated the GtH releasing activity of LRH-Aa in goldfish, causing oocyte maturation and ovulation in goldfish held at $12^{\circ} \mathrm{C}$. Preliminary studies on common carp indicate that pimozide has a similar action to potentiate the effects of LRH-Aa on GtH release and that this combination may be useful for inducing ovulation in this species also. Spontaneous ovulation and spawning of goldfish normally occurs at temperatures of about $20^{\circ} \mathrm{C}$ (Yamamoto 
et al., 1966). In the present work we have investigated the effects of LRH-Aa injections, implantation of pellets containing an analogue of $\mathrm{LH}-\mathrm{RH}$, and the combination of these treatments with injection of pimozide on GtH secretion and ovulation in goldfish at $18-20^{\circ} \mathrm{C}$ in an attempt to develop a procedure for reliably inducing ovulation within a 24-h period.

\section{MATERIALS AND METHODS}

Goldfish, common or comet variety, were held prior to the experiments in 3200-1 flow-through aquaria at $13-15^{\circ} \mathrm{C}$ and a $12 \mathrm{~h}$ light: $12 \mathrm{~h}$ dark (12L:12D) photoperiod.

Sexually mature (gravid) females were selected for the experiments by gently squeezing the abdomen to eject a few oocytes from the ovipore to confirm the presence of oocytes that had completed vitellogenesis. Each fish was individually tagged and weighed $4-7$ days before an experiment, and acclimated to $13-15^{\circ} \mathrm{C}$ and a $16 \mathrm{~L}: 8 \mathrm{D}$ photoperiod in $150-1$ aquaria. Fish were fed twice daily ad libitum with Ewos trout pellets. At $16 \mathrm{~h}$ before the beginning of each experiment (except Experiment 5) the water temperature was warmed to $18-20^{\circ} \mathrm{C}$.

Des Gly $^{10}\left[\mathrm{D}-\mathrm{Ala}^{6}\right]-\mathrm{LH}-\mathrm{RH}-\mathrm{ethylamide}$ (LRH-Aa) was purchased from Sigma, St. Louis, MO, U.S.A., or Syndel Laboratories, Vancouver, B.C., Canada. LRH-Aa was dissolved in freshwater teleost physiological solution (PS; Burnstock, 1958) and injected intraperitoneally (i.p.) at a dose of $0.1 \mu \mathrm{g} / \mathrm{g}$ body weight $(5 \mu \mathrm{l} / \mathrm{g}$ body weight). Cholesterol pellets containing des-Gly ${ }^{10}\left[\mathrm{D}-\operatorname{Trp}^{6}\right]-\mathrm{LH}-\mathrm{RH}$-ethylamide (LRH-At) were a gift from Syntex Inc., Palo Alto, CA (pellets RS 84 137, batch 4299-PPW-072). To implant the $25 \mathrm{mg}$ pellets (low dose pellets containing $25 \mu \mathrm{g}$ LRH-At; high dose pellets containing $125 \mu \mathrm{g}$ LRH-At), fish were anaesthetized, an aperture made in the body wall with sharp-pointed forceps and the pellet implanted intraperitoneally via a plastic cone inserted into the hole in the body wall. Sham operated fish were treated similarly except no pellet was implanted.

Pimozide was a gift from Janssen Pharmaceuticals Ltd., Beerse, Belgium. Pimozide was suspended in a vehicle of $0.7 \% \mathrm{NaCl}$ with $0.1 \%$ sodium metabisulphite, and injected i.p. at a dose of $10 \mu \mathrm{g} / \mathrm{g}$ body weight $(10 \mu \mathrm{l} / \mathrm{g}$ body weight). Control fish were injected i.p. with PS and/or the pimozide vehicle (vehicle). The details of treatment in various experimental groups are summarized in Table I. Procedures for fish handling, blood sampling and measurement of serum GtH by radioimmunoassay have been described (Crim et al., 1976; Hontela and Peter, 1978, 1980; Chang et al., 1983). In Experiments 1-4, ovulation was checked by stripping at the time of bleeding (see Table I); in Experiment 7 ovulation was checked at 7, 11, 14, 24, 29, 50 and $76 \mathrm{~h}$ after pimozide injection. In Experiments 5 and 6 ovulation was checked at 09.00 and $17.00 \mathrm{~h}$ daily.

The Mann-Whitney $U$ test (two-tailed) was used to compare serum 
TABLE I

Treatment in the various experimental groups

\begin{tabular}{|c|c|c|c|}
\hline \multirow{2}{*}{$\begin{array}{l}\text { Experi- } \\
\text { ment }\end{array}$} & \multicolumn{2}{|l|}{ Treatments } & \multirow{2}{*}{$\begin{array}{l}\text { Blood samples: hours } \\
\text { after } 2 \text { nd injection } \\
\text { (Expts. } 1,2,3,4 \text { and } 7 \text { ) } \\
\text { or days after implantation } \\
\text { (Expts. } 5 \text { and } 6 \text { ) }\end{array}$} \\
\hline & $\begin{array}{l}\text { First injection or } \\
\text { pellet implantation }\end{array}$ & Second injection & \\
\hline 1 & $\begin{array}{l}09.00 \\
\text { PS } \\
\text { PS } \\
\text { LRH-Aa } \\
\text { LRH-Aa }\end{array}$ & $\begin{array}{l}12.00 \\
\text { PS+vehicle } \\
\text { PS+pimozide } \\
\text { LRH-Aa+vehicle } \\
\text { PS+pimozide }\end{array}$ & $\begin{array}{l}\text { Pre-sample } \\
3,24 \mathrm{~h}\end{array}$ \\
\hline 2 & $\begin{array}{l}09.00 \\
\text { PS+vehicle } \\
\text { PS+pimozide } \\
\text { LRH-Aa+vehicle } \\
\text { LRH-Aa+pimozide }\end{array}$ & $\begin{array}{l}12.00 \\
\text { PS } \\
\text { PS } \\
\text { LRH-Aa } \\
\text { LRH-Aa }\end{array}$ & $6,20 \mathrm{~h}$ \\
\hline 3 & $\begin{array}{l}09.00 \\
\text { Vehicle } \\
\text { Pimozide } \\
\text { Vehicle } \\
\text { Pimozide }\end{array}$ & $\begin{array}{l}12.00 \\
\text { PS } \\
\text { PS } \\
\text { LRH-Aa } \\
\text { LRH-Aa }\end{array}$ & $6,20 \mathrm{~h}$ \\
\hline 4 & $\begin{array}{l}\text { Not injected } \\
\text { Not injected } \\
\text { Not injected } \\
\text { Not injected }\end{array}$ & $\begin{array}{l}09.00 \\
\text { PS+vehicle } \\
\text { PS+pimozide } \\
\text { LRH-Aa+vehicle } \\
\text { Pimozide+LRH-Aa }\end{array}$ & $6,24 \mathrm{~h}$ \\
\hline $\begin{array}{l}5 \\
\left(12^{\circ} \mathrm{C}\right)\end{array}$ & $\begin{array}{l}17.00 \\
\text { Sham control } \\
\text { LRH-At pellet } \\
\text { (low dose) } \\
\text { LRH-At pellet } \\
\text { (high dose) }\end{array}$ & $\begin{array}{l}\text { No second } \\
\text { injection }\end{array}$ & $2,4,6,8$ days \\
\hline 6 & $\begin{array}{l}17.00 \\
\text { Sham control } \\
\text { LHR-At pellet } \\
\text { (low dose) } \\
\text { LRH-At pellet } \\
\text { (high dose) }\end{array}$ & $\begin{array}{l}\text { No second } \\
\text { injection }\end{array}$ & $1,3,5,7$ days \\
\hline 7 & $\begin{array}{l}15.00 \\
\text { Sham control } \\
\text { Sham control } \\
\text { LRH-At pellet } \\
\text { (low dose) } \\
\text { LRH-At pellet } \\
\text { (high dose) }\end{array}$ & $\begin{array}{l}09.00 \\
\text { Vehicle } \\
\text { Pimozide } \\
\text { Vehicle } \\
\text { Pimozide }\end{array}$ & $6,76 \mathrm{~h}$ \\
\hline
\end{tabular}

${ }^{a}$ A pre-injected blood sample was taken at $09.00 \mathrm{~h}$ for Expt. 1. 
GtH concentrations between different treatment groups, and the Wilcoxon rank sum test (two-tailed) was used to compare GtH values between preinjection and post-injection samples. To compare the number of ovulated fish between groups, the Fisher's exact one-tail test was used.

\section{RESULTS}

In experiment I (Table II), at $3 \mathrm{~h}$ after the second injection the mean serum GtH concentrations in the PS and PS+pimozide (solutions for first injection and second injection, see Table I), LRH-Aa and LRH-Aa+vehicle, and LRH-Aa and PS+pimozide injected groups were significantly higher than their respective pre-samples. At this time serum GtH levels in the LRH-Aa and LRH-Aa+vehicle, and LRH-Aa and PS+pimozide groups were significantly higher compared to PS and PS+vehicle, and PS and PS+pimozide injected fish. At $24 \mathrm{~h}$ after the second injection, serum GtH levels in the two LRH-Aa groups were still significantly higher compared to their pre-samples, but only the LRH-Aa and LRH-Aa+vehicle injected group was significantly higher compared to the PS and PS+vehicle group, and the PS and PS+pimozide group. By $24 \mathrm{~h}$, two fish ovulated in the LRH-Aa and PS+pimozide injected group; however, this number of ovulated fish was not statistically significant compared to the other groups which had no ovulations.

\section{TABLE II}

Efffects of pimozide given after a single injection of LRH-Aa on serum gonadotropin levels and ovulation in female goldfish held at $18-20^{\circ} \mathrm{C}$ (Experiment 1 )

Serum gonadotropin $(\mathrm{ng} / \mathrm{ml})^{\mathfrak{a}}$ at times after second injection

\begin{tabular}{|c|c|c|c|c|}
\hline $\begin{array}{l}\text { First injection } \\
(09.00 \mathrm{~h}) \\
\text { Second injection } \\
(12.00 \mathrm{~h})\end{array}$ & $\begin{array}{l}\text { PS } \\
\text { PS+vehicle }\end{array}$ & $\begin{array}{l}\text { PS } \\
\text { PS+pimozide }\end{array}$ & $\begin{array}{l}\text { LRH-Aa } \\
\text { LRH-Aa+vehicle }\end{array}$ & $\begin{array}{l}\text { LRH-Aa } \\
\text { PS+pimozide }\end{array}$ \\
\hline \multicolumn{5}{|l|}{ Pre-sample* } \\
\hline $\begin{array}{l}(09.00 \mathrm{~h}) \\
3 \mathrm{~h}\end{array}$ & $4.8 \pm 0.6$ & $3.4 \pm 0.5$ & $3.6 \pm 0.4$ & $\begin{array}{c}3.7 \pm 0.8 \\
\end{array}$ \\
\hline $\begin{array}{l}(15.00 \mathrm{~h}) \\
24 \mathrm{~h}\end{array}$ & $6.1 \pm 1.5$ & $8.4 \pm 2.5^{c}$ & $42.5 \pm 17.8^{b, c}$ & $111.2 \pm 40.8^{0, c}$ \\
\hline $\begin{array}{l}(12.00 \mathrm{~h}) \\
\text { Ovulations }\end{array}$ & $\begin{array}{l}5.8 \pm 1.4 \\
0 / 7\end{array}$ & $\begin{array}{l}4.3 \pm 0.8 \\
0 / 7\end{array}$ & $\begin{array}{l}22.6 \pm 7.1^{b, c} \\
0 / 7\end{array}$ & $\begin{array}{l}68.8 \pm 53.5^{c} \\
2 / 7\end{array}$ \\
\hline
\end{tabular}

aMean $\pm S E$.

${ }^{b}$ Significantly different from PS and PS+vehicle, and PS and PS+pimuzide groups al same sample time $(P<0.05)$.

'Significantly different from pre-sample $(P<0.05)$.

$*$ Pre-sample taken at time of first injection. 


\section{TABLE III}

Effects of pimozide at the first of two injections of LRH-Aa on serum gonadotropin levels and ovulation in female goldfish held at $18-20^{\circ} \mathrm{C}$ (Experiment 2)

Serum gonadotropin $(\mathrm{ng} / \mathrm{ml})^{\mathrm{a}}$ at times after second injection

First injection

$(09.00 \mathrm{~h})$

Second injection

$(12.00 \mathrm{~h})$

PS+vehicle

PS+pimozide

LRH-Aa+vehicle

LRH-Aa+pimozide

\begin{tabular}{lllll}
$(12.00 \mathrm{~h})$ & PS & PS & LRH-Aa & LRH-Aa \\
\hline $6 \mathrm{~h}$ & $6.9 \pm 1.2$ & $22.4 \pm 9.7$ & $189 \pm 42^{\mathrm{b}, \mathrm{c}}$ & $422 \pm 111^{\mathrm{b}, \mathrm{c}}$ \\
$20 \mathrm{~h}$ & $4.4 \pm 0.4$ & $12.4 \pm 3.7$ & $112 \pm 48^{\mathrm{b}, \mathrm{c}}$ & $767 \pm 140^{\mathrm{d}}$ \\
Ovulations & $0 / 7$ & $0 / 7$ & $2 / 8$ & $7 / 8^{\mathrm{e}}$ \\
\hline
\end{tabular}

${ }^{a}$ Mean \pm SE.

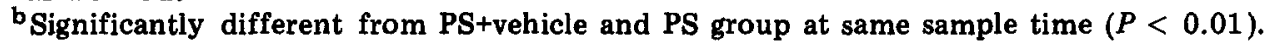
'Significantly different from PS+pimozide and PS group at same sample time $(P<0.05)$.

${ }^{d}$ Significantly different from all other groups at same sample time $(P<0.01)$.

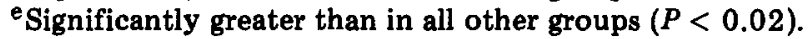

\section{TABLE IV}

Effects of pimozide followed by a single injection of LRH-Aa on serum gonadotropin levels and ovulation in female goldfish held at $18-20^{\circ} \mathrm{C}$ (Experiment 3 )

Serum gonadotropin $(\mathrm{ng} / \mathrm{ml})^{\mathrm{a}}$ at times after second injection

First injection

$(09.00 \mathrm{~h})$

-

Second injection

$(12.00 \mathrm{~h})$

Vehicle Pimozide Vehicle Pimozide

\begin{tabular}{lllll}
\hline $6 \mathrm{~h}$ & $16.1 \pm 7.4$ & $79.2 \pm 28.6^{\mathrm{b}}$ & $159 \pm 46^{\mathrm{b}}$ & $652 \pm 125^{\mathrm{c}}$ \\
$20 \mathrm{~h}$ & $49.7 \pm 43.1$ & $35.6 \pm 11.1$ & $62.7 \pm 28.5$ & $642 \pm 150^{\mathrm{c}}$ \\
Ovulations & $0 / 7$ & $0 / 7$ & $2 / 8$ & $7 / 8^{\mathrm{d}}$ \\
\hline
\end{tabular}

${ }^{\mathrm{a}} \mathrm{Mean} \pm \mathrm{SE}$.

${ }^{\mathrm{b}}$ Significantly different from vehicle and PS group at same sample time $(P<0.05)$.

c Significantly different from all other groups at same sample time $(P<0.01)$.

dSignificantly greater than in all other groups $(P<0.02)$.

In Experiment 2 (Table III), at $6 \mathrm{~h}$ after the second injection, serum GtH concentrations were significantly higher in the LRH-Aa+vehicle and LRH-Aa group, and the LRH-Aa+pimozide and LRH-Aa group compared to PS+vehicle and PS, and PS+pimozide and PS groups. At $20 \mathrm{~h}$ after the second injection, serum GtH levels in fish injected with LRH-Aatvehicle and LRH-Aa were significantly higher than that in groups injected with PS+vehicle and PS, and PS+pimozide and PS. However, fish given LRHAatpimozide and LRH-Aa had serum GtH concentrations significantly 
higher than that of all other treatment groups; the number of ovulated fish (seven out of eight) was also significantly higher than in all other groups.

In Experiment 3 (Table IV), at $6 \mathrm{~h}$ after the second injection the serum GtH levels in the pimozide and PS, and vehicle and LRH-A groups were significantly higher than that in the vehicle and PS group. Also, at the same sample time serum GtH concentrations in the pimozide and LRHAa group were significantly higher compared to all other groups. At 20 $h$ after the second injection the serum GtH levels in the pimozide and LRH-Aa group were significantly higher than that in all other groups; there were no significant differences in serum GtH concentrations between the other groups at $24 \mathrm{~h}$. By $20 \mathrm{~h}$ seven out of eight fish ovulated in the pimozide and LRH-Aa group, significantly more than in each of the other treatment groups. The number of ovulated fish in the vehicle and LRH-Aa injected group (two out of eight) was not significantly higher than in the vehicle and PS, and pimozide and PS treatment groups, which had no ovulated fish.

In Experiment 4 (Table V), at $6 \mathrm{~h}$ after injection the serum GtH levels in the PS+pimozide group, and the LRH-Aa+vehicle group were significantly higher than in the PS+vehicle group. At the same sample time serum GtH concentrations in LRH-Aa+pimozide injected fish were significantly higher than in all the other groups. At $24 \mathrm{~h}$ after injection, GtH levels were significantly higher in fish from the PS+pimozide group compared to the PS+vehicle group, and in the LRH-Aa+pimozide group compared to PS+vehicle, and LRH-Aa+vehicle groups. By $24 \mathrm{~h}$ after the injections some ovulations were observed in all groups except the PS+vehicle group, but only the number of fish ovulated in the LRH-Aa+pimozide group (five out of eight) was significantly higher than in the PS+vehicle group.

In Experiment 5 (Table VI) pellets containing LRH-Aa were implanted into fish held at $12^{\circ} \mathrm{C}$. At $2,4,6$ and 8 days after implantation serum GtH

\section{TABLE V}

Effects of a single injection of pimozide and LRH-Aa on serum gonadotropin levels and ovulation in female goldfish held at $18-20^{\circ} \mathrm{C}$ (Experiment 4 ):

\begin{tabular}{lllll}
\hline & \multicolumn{4}{l}{ Serum gonadotropin $(\mathrm{ng} / \mathrm{ml})^{\mathrm{a}}$ at times after second injection } \\
\cline { 2 - 5 } & PS+vehicle & PS+pimozide & LRH-Aa+vehicle & LRH-Aa+pimozide \\
\hline $6 \mathrm{~h}$ & $8.5 \pm 1.7$ & $162 \pm 43^{\mathrm{b}}$ & $80.7 \pm 29.8^{\mathrm{b}}$ & $547 \pm 119^{\mathrm{d}}$ \\
$\mathbf{2 4} \mathrm{h}$ & $8.3 \pm 1.7$ & $149 \pm 61^{\mathrm{b}}$ & $53.2 \pm 36.4$ & $396 \pm 105^{\mathrm{b}, \mathrm{c}}$ \\
Ovulations & $0 / 7$ & $3 / 7$ & $1 / 8$ & $5 / 8^{\mathrm{e}}$ \\
\hline
\end{tabular}

aean $\pm \mathrm{SE}$.

bSignificantly different from PS+vehicle group at same sample time $(P<0.05)$.

cSignificantly different from LRH-Aa+vehicle group at same sample time $(P<0.01)$.

d Significantly different from all other groups at same sample time $(P<0.05)$.

${ }^{e}$ Significantly greater than in PS+vehicle group $(P<0.05)$. 
TABLE VI

Effects of LRH-At implanted pellets on serum gonadotropin levels and ovulation in female goldfish held at $12-14^{\circ} \mathrm{C}$ (Experiment 5)

\begin{tabular}{llll}
\hline & \multicolumn{3}{l}{ Serum gonadotropin $(\mathrm{ng} / \mathrm{ml})^{\mathrm{a}}$ at days after pellet implantation } \\
\cline { 2 - 4 } & Sham control & Low dose pellet & High dose pellet \\
\hline 2 days & $6.9 \pm 0.9$ & $86.8 \pm 26.2^{\mathrm{b}}$ & $69.9 \pm 15.5^{\mathrm{b}}$ \\
4 days & $4.7 \pm 0.6$ & $178 \pm 71^{\mathrm{b}}$ & $85.6 \pm 20.8^{\mathrm{b}}$ \\
6 days & $6.1 \pm 1.5$ & $80.8 \pm 25.7^{\mathrm{b}}$ & $144 \pm 23.2^{\mathrm{b}}$ \\
8 days & $6.4 \pm 1.1$ & $129 \pm 33^{\mathrm{b}}$ & $140 \pm 29^{\mathrm{b}}$ \\
Ovulations & $0 / 8$ & $2 / 8$ & $2 / 9$ \\
\hline
\end{tabular}

${ }^{a}$ Mean \pm SE.

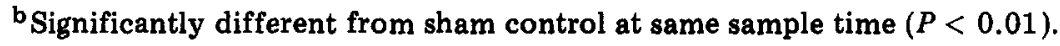

\section{TABLE VII}

Effects of LRH-At implanted pellets on serum gonadotropin levels and ovulation in female goldfish held at $18-20^{\circ} \mathrm{C}$ (Experiment 6)

\begin{tabular}{llcc}
\hline & \multicolumn{3}{l}{ Serum gonadotropin $(\mathrm{ng} / \mathrm{ml})^{\mathrm{a}}$ at days after pellet implantation } \\
\cline { 2 - 4 } & Sham control & Low dose pellet & High dose pellet \\
\hline 1 day & $6.2 \pm 0.5$ & $97.2 \pm 30.3^{\mathrm{b}}$ & $185.5 \pm 71.4^{\mathrm{b}}$ \\
3 days & $4.7 \pm 0.6$ & $76.9 \pm 29.3^{\mathrm{b}}$ & $69.4 \pm 25.5^{\mathrm{b}}$ \\
5 days & $6.3 \pm 1.1$ & $171.4 \pm 67.9^{\mathrm{b}}$ & $68.1 \pm 16.1^{\mathrm{b}}$ \\
7 days & $9.3 \pm 0.9$ & $29.3 \pm 4.9^{\mathrm{b}}$ & $63.7 \pm 26.4^{\mathrm{b}}$ \\
Ovulations & $0 / 9$ & $0 / 8$ & $4 / 8^{\mathrm{c}}$ \\
& & & $(24-48 \mathrm{~h})$ \\
\hline
\end{tabular}

${ }^{a}$ Mean \pm SE.

bSignificantly different from sham control at same sample time $(P<0.01)$.

c Signficantly greater than in all other groups $(P<0.05)$.

levels were significantly higher in the groups that received the LRH-At pellets in the sham controls; however, serum GtH levels did not change significantly with time in either of the LRH-At implanted groups and there were no significant differences between the low dose versus the high dose pellet groups at any sample time. Two fish ovulated in each LRH-At pellet implant group, but this number of ovulated fish was not significantly higher from the sham group in which no ovulations occurred.

In Experiment 6 (Table VII) LRH-At pellets were implanted into fish held at $20^{\circ} \mathrm{C}$. At $1,3,5$ and 7 days after implantation serum GtH levels were significantly higher in both LRH-At pellet implant groups than in the sham controls. There were no significant differences between the two pellet implant groups at any sample time; however, the low dose implant group had significantly lower serum GtH levels at 7 days compared to 
TABLE VIII

Effects of LRH-At implanted pellets (low dose) followed $18 \mathrm{~h}$ later by pimozide injection on gonadotropin levels and ovulation in female goldfish held at $18-20^{\circ} \mathrm{C}$ (Experiment 7 )

\begin{tabular}{|c|c|c|c|c|}
\hline \multirow{2}{*}{$\begin{array}{l}\text { Implantation } \\
\text { injection }\end{array}$} & \multicolumn{4}{|c|}{ Serum gonadotropin $(\mathrm{ng} / \mathrm{ml})^{\mathrm{a}}$ at times after injection } \\
\hline & Sham+vehicle & Sham+pimozide & $\begin{array}{l}\text { LRH-At pellets } \\
\text { +vehicle }\end{array}$ & $\begin{array}{l}\text { LRH-At pellets } \\
\text { +pimozide }\end{array}$ \\
\hline $\begin{array}{l}6 \mathrm{~h} \\
76 \mathrm{~h} \\
\text { Ovulations }\end{array}$ & $\begin{array}{l}25.8 \pm 14.4 \\
15.0 \pm 4.1 \\
2 / 7 \\
(24,50 \mathrm{~h})\end{array}$ & $\begin{array}{l}14.9 \pm 4.7 \\
8.1 \pm 0.7 \\
1 / 7 \\
(29 \mathrm{~h})\end{array}$ & $\begin{array}{l}171 \pm 46^{\mathrm{b}} \\
450 \pm 120^{\mathrm{b}} \\
3 / 8 \\
(30-50 \mathrm{~h})\end{array}$ & $\begin{array}{l}299 \pm 92^{\mathrm{b}} \\
1136 \pm 446^{\mathrm{b}} \\
7 / 8^{\mathrm{c}} \\
(7-29 \mathrm{~h})\end{array}$ \\
\hline
\end{tabular}

${ }^{a}$ Mean $\pm \mathrm{SE}$.

${ }^{b}$ Significantly different from sham+pimozide, and sham+vehicle groups at same sample time $(P<0.01)$.

${ }^{c}$ Significantly greater than in sham+vehicle, and sham+pimozide groups $(P<0.05)$.

5 days post-implantation. The number of ovulations in the high dose pellet implanted fish (four out of eight) was significantly higher than in the other two groups.

In Experiment 7 (Table VIII), at $6 \mathrm{~h}$ after pimozide or vehicle injection the serum GtH levels in LRH-At pellet and vehicle, and LRH-At pellet and pimozide groups were significantly higher compared to sham and vehicle, and sham and pimozide groups; at $76 \mathrm{~h}$ after injection the serum GtH concentrations in these groups were still significantly higher than in the sham and vehicle, and sham and pimozide groups. Ovulations occurred in all treatment groups; the number of ovulated fish in the LRH-At pellet and pimozide group (seven out of eight) was significantly higher compared to sham and vehicle, and sham and pimozide groups.

\section{DISCUSSION}

LRH-Aa, given as a single i.p. injection or two injections $3 \mathrm{~h}$ apart at $0.1 \mu \mathrm{g} / \mathrm{g}$ body weight per injection, caused increased serum GtH levels lsting at least $24 \mathrm{~h}$ in mature female goldfish. One injection was about as effective as two injections in terms of the serum GtH levels measured; however, there was a large variability in the response. Some ovulations did occur within $24 \mathrm{~h}$ after LRH-Aa injection ( $\leqslant 25 \%$ ). However, such a rate of ovulation is too low to be considered as an efficient technique for applied purposes; also, this ovulation rate was not significantly different by Fisher's exact one-tail test from the vehicle+PS injected control groups, which had no ovulations. In previous experiments ovulation was found only rarely later than $24 \mathrm{~h}$ after injection(s) of LRH-Aa (R. Peter, unpublished data, 1977-1981). The serum GtH levels induced by LRH-Aa were similar to those found by Chang and Peter (1983b) after 
LHR-Aa injection in mature female goldfish at $12^{\circ} \mathrm{C}$; no ovulations were reported in response to $\mathrm{LRH}$-Aa in goldfish at $12^{\circ} \mathrm{C}$.

Injection of pimozide, a dopamine antagonist, caused a significant increase in serum GtH levels in mature female goldfish in only two of five experiments. Pimozide was previously reported to cause a significant, although variable, increase in serum GtH levels in mature female goldfish at $12^{\circ} \mathrm{C}$ (Chang and Peter, 1983a,b); ovulation was not observed in this work, except for one animal (one of 15 fish in two experiments).

In a previous study by Chang and Peter $(1983 \mathrm{~b})$ on mature female goldfish at $12^{\circ} \mathrm{C}$ it was found that pimozide injected with the first or second of two LRH-Aa injections (12-h injection interval), or prior to a single injection of LRH-Aa, greatly potentiated the GtH release-response to LRHAa; simultaneous injection of pimozide and LRH-Aa was less effective. The ovulation rate ranged from $100 \%$ for pimozide injected with the second of two LRH-Aa injections, to 37\% (three out of eight) for simultaneous injection. In the present study on mature female goldfish at $18-20^{\circ} \mathrm{C}$, very effective conditions for stimulating $\mathrm{GtH}$ release were injection of pimozide prior to LRH-Aa (3-h injection interval), injection of pimozide with the first of two injections of LRH-Aa, or a single simultaneous injection; pimozide following a single LRH-Aa injection (3-h injection interval) was less effective. A high occurrence of ovulation (seven out of eight) was induced within $23 \mathrm{~h}$ by injection of pimozide with the first of two injections of LRH-Aa, or prior to a single injection of LRH-Aa; simultaneous injection was relatively less effective (five out of eight). The precise time of ovulation of each fish was not noted; however, there were no ovulated fish at $6 \mathrm{~h}$ after the second injection in any experiment (9 $\mathrm{h}$ after first injections). In mature female goldfish at $20^{\circ} \mathrm{C}$, ovulation occurs between 9.5 to $13 \mathrm{~h}$ after injection of salmon GtH or human chorionic gonadotropin (Stacey et al, 1979b). Ovulation in goldfish at $18-20^{\circ} \mathrm{C}$ in jected with pimozide and LRH-Aa may be within a similar time frame; however, further studies are necessary to determine precisely the time of ovulation.

Intraperitoneal implantation of pellets providing a continuous release of LRH-At caused a relatively steady increase in serum GtH levels for at least 8 days at $12^{\circ} \mathrm{C}$, and at least 7 days at $18-20^{\circ} \mathrm{C}$ in mature female goldfish. Although pellets with a low $(25 \mu \mathrm{g})$ and high $(125 \mu \mathrm{g})$ content of LRH-At were used, there was no significant difference in the serum GtH levels induced between the two treatments, at either $12^{\circ} \mathrm{C}$ or $18-$ $20^{\circ} \mathrm{C}$. However, there must have been a difference in the rate of release of LRH-At from the pellets because at $18-20^{\circ} \mathrm{C}$ the occurrence of ovulation in fish implanted with the high dose pellets was 50\% (four out of eight), whereas no ovulations occurred in the fish given the low dose pellets. Perhaps the initial stimulation of $\mathrm{GtH}$ release by the high dose pellets in fish at $18-20^{\circ} \mathrm{C}$ was greater than with the low dose pellets, although at $24 \mathrm{~h}$ after implantation both groups had similar GtH levels. From pre- 
vious work it was suggested that the rate of increase in blood GtH concentration, and not just the absolute level, may be important for inducing ovulation in goldfish (Chang and Peter, 1983b). Crim et al. (1983) used similar high dose LRH-At pellets in landlocked Atlantic salmon to induce a chronic increase in plasma GtH levels; all the implanted salmon ovulated at least 2 weeks earlier than the control fish. Thus, although implantation of pellets that give a continuous release of analogue, causing a chronic increase in blood GtH, may be useful for inducing ovulation in species such as salmonids, such a technique has limited usefulness in goldfish. On the other hand, when pimozide was injected into fish previously implanted with a low dose LHR-At pellet, there was a high occurrence of ovulation (seven out of eight) within $29 \mathrm{~h}$ of injection. Interestingly, although the serum GtH levels in the LRH-At pellet and pimozide treated fish were high, particularly at $76 \mathrm{~h}$, there were no significant differences in the serum GtH levels between this group and the LRH-At and vehicle treated fish due to the great variability within each group.

The present results confirm that pimozide, a dopamine antagonist, greatly potentiates the GtH release-response to superactive analogues of $\mathrm{LH}-\mathrm{RH}$ in goldfish. This further supports the idea that dopamine acts directly at the pituitary level as a GtH release-inhibitory factor (Chang and Peter, 1983a). Injection of pimozide $3 \mathrm{~h}$ prior to injection of LHR-Aa, or with the first of two LRH-Aa injections given $3 \mathrm{~h}$ apart, were highly effective procedures for inducing ovulation within $24 \mathrm{~h}$ of treatment in goldfish at $18-20^{\circ} \mathrm{C}$, whereas injection of pimozide following LRH-Aa injection, or injection of LRH-Aa alone, were relatively ineffective. Implantation of pellets that give continuous release of LRH-At was relatively ineffective for inducing ovulation. However, injection of pimozide into fish previously implanted with LRH-At pellets, and therefore continuously exposed to the analogue, was highly effective for inducing ovulation. These results provide valuable information for the application of analogues of $\mathrm{LH}-\mathrm{RH}$ and pimozide for inducing ovulation in goldfish at $18-20^{\circ} \mathrm{C}$, a usual temperature for ovulation in goldfish. To understand more fully the interaction of pimozide and $\mathrm{LH}-\mathrm{RH}$ analogues in stimulating $\mathrm{GtH}$ release in goldfish, further studies are necessary to determine the importance of the timing of the injections relative to each other, and the full range of dosages of pimozide and $\mathrm{LRH}$ analogue that are effective.

Based on the results of these studies on goldfish, a preliminary study was designed to test whether treatment with pimozide and $\mathrm{LH}-\mathrm{RH}$ analogue would be effective for inducing ovulation in common carp (Billard et al., 1983). The results indicate that injection of pimozide followed by $\mathrm{LH}-\mathrm{RH}$ analogue $6 \mathrm{~h}$ later is effective at increasing the GtH release-response to the analogue. Although this experiment was conducted in August, several months past the normal spawning time for common carp, complete ovulation was induced in three fish, one fish had partial ovulation and the remaining three fish in the pimozide and $\mathrm{LH}-\mathrm{RH}$ analogue test group 
had oocyte maturation. This indicates that dopamine has GRIF activity in carp, similar to goldfish. Furthermore, it is apparent that the combined treatment with the dopamine receptor antagonist pimozide and $\mathrm{LH}-\mathrm{RH}$ superactive analogue should be highly effective for induction of ovulation in carp that have completed vitellogenesis prior to or during the normal spawning season. Further studies are required to determine the minimal dosages of pimozide and $\mathrm{LH}-\mathrm{RH}$ analogue necessary to induce ovulation in common carp, and to determine the efficacy of this treatment regime for inducing ovulation in other teleost species.

\section{ACKNOWLEDGEMENTS}

This research was supported by grants G0838 and A6371 to R.E.P. from the National Sciences and Engineering Research Council of Canada. The visit by C.W. to Canada was supported by a France-Canada Exchange Scientist grant.

\section{REFERENCES}

Billard, R, Alagarswami, K., Peter, R.E. and Breton, B., 1983. Potentialisation par le pimozide des effets du LHRH-A sur la sécrétion gonadotrope hypophysaire l'ovulation et la spermiation chez la carpe commune (Cyprinus carpio). C.R. Acad. Sci. Paris, 296 (Serie III) : 181-184.

Burnstock, G., 1958. Saline for fresh-water fish. J. Physiol., 141: 35-44.

Chang, J.P. and Peter, R.E., 1983a. Effects of dopamine on gonadotropin release in female goldfish, Carassius auratus. Neuroendocrinology, 36: 351-357.

Chang, J.P. and Peter, R.E., 1983b. Effects of pimozide and des Gly ${ }^{10},\left[D-\mathrm{Ala}^{6}\right]$ luteinizing hormone-releasing hormone ethylamide on serum gonadotropin concentrations, germinal vesicle migration and ovulation in female goldfish, Carassius auratus. Gen. Comp. Endocrinol., in press.

Chang, J.P., Cook, A.F. and Peter, R.E., 1983. Influence of catecholamines on gonadotropin secretion in goldfish, Carassius auratus. Gen. Comp. Endocrinol., 49: 22-31.

Cooperative Team for Hormonal Application in Pisciculture, 1977. A new highly effective ovulating agent for fish reproduction - practical application of LH- RH analogue for the induction of spawning of farm fishes. Sci. Sinica, 20: 469-474.

Crim, L.W., Evans, D.M. and Vickery, B.H., 1983. Manipulation of the seasonal reproductive cycle of the landlocked salmon (Salmo salar) by LHRH analogues administered at various stages of gonadal development. Can. J. Fish. Aquatic Sci., 40: 61-67.

Crim, L.W., Peter, R.E. and Billard, R., 1976. Stimulation of gonadotropin secretion by intraventricular injection of hypothalamic extracts in the goldfish, Carassius auratus. Gen. Comp. Endocrinol., 30: 77-82.

Donaldson, E.M., Hunter, G.A. and Dye, H.M., 1981/9182. Induced ovulation in coho salmon (Oncorhynchus kisutch). II. Preliminary study of the use of LH-RH and two high potency LH-RH analogues. Aquaculture, 26: 129-141.

Fish Reproductive Physiology Research Group, and Peptide Hormone Group, 1978. Radioimmunoassay on serum gonadotropin of carp (Cyprinus carpio L.). Acta Biochim. Biophys. Sinica, 10: 399-407.

Fostier, A., Weil, C., Terqui, M., Breton, B. and Jalabert, B., 1978. Plasma estradiol$17 \beta$ and gonadotropin during ovulation in rainbow trout (Salmo gairdneri R.) Ann. Biol. Anim., Biochim., Biophys., 18: 929-936. 
Fukien-Kiangsu-Chekiang-Shanghai Cooperative Group for Artificial Reproduction of Fresh-Water Economic Fishes, 1977. A further investigation on the stimulatory effect of a synthetic analogue of hypothalamic luteinizing hormone releasing hormone (LRH-A) on spawning in "domestic fishes". Acta Biochim. Biophys. Sinica, 9: 15-24.

Hontela, A. and Peter, R.E., 1978. Daily cycles in serum gonadotropin levels in the goldfish: effects of photoperiod, temperature, and sexual condition. Can. J. Zool., 56: 2430-2442.

Hontela, A. and Peter, R.E., 1980. Effects of pinealectomy, blinding and sexual condition on serum gonadotropin levels in the goldfish. Gen. Comp. Endocrinol., 40: 168-179.

Jalabert, B. and Breton, B., 1980. Evolution de la gonadotropine plasmatique t-GtH après l'ovulation chez la truite arc-en-ciel (Salmo gairdneri R.) et influence de la rétention des ovules, C.R. Acad. Sci. Paris, Ser. D, 290: 799-801.

Jiang, R., Huang, S. and Zhao, W, 1980. Changes of serum gonadotropin levels before and behind induced spawning in grass carp and silver carp. J. Fish. China, 4: 129-133.

Lam, T.J., Pandey, S. and Hoar, W.S., 1975. Induction of ovulation in goldfish by synthetic luteinizing hormone-releasing hormone (LH-RH). Can. J. Zool., 53: 11891192.

Peter, R.E., 1980. Serum gonadotropin levels in mature male goldfish in response to luteinizing hormone-releasing hormone $(\mathrm{LH}-\mathrm{RH})$ and des-Gly ${ }^{10}-\left[\mathrm{D}-\mathrm{Ala}{ }^{6}\right]-\mathrm{LH}-\mathrm{RH}$ ethylamide. Can. J. Zool., 58: 1100-1104.

Peter, R.E., 1982. Neuroendocrine control of reproduction in teleosts. Can. J. Fish. Aquat. Sci, 39: 48-55.

Peter, R.E., 1983. The brain and neurohormones in teleost reproduction. In: W.S. Hoar, D.J. Randall and E.M. Donaldson (Editors), Fish Physiology, Vol. 9. Academic Press, New York, NY, pp. 97-135.

Stacey, N.E., Cook, A.F. and Peter, R.E., 1979a. Ovulatory surge of gonadotropin in the goldfish, Carassius auratus. Gen. Comp. Endocrinol., 37: 246-249.

Stacey, N.E., Cook, A.F. and Peter, R.E., 1979b. Spontaneous and gonadotropin-induced ovulation in the goldfish, Carassius auratus L.; effects of external factors. J. Fish Biol., 15: 349-361.

Van Der Kraak, G.J., Lin. H.R., Donaldson, E.M., Dye, H.M. and Hunter, G.A., 1983. Effects of $\mathrm{LH}-\mathrm{RH}$ and des $\mathrm{Gly}^{10}\left[\mathrm{D}-\mathrm{Ala}^{6}\right] \mathrm{LH}-\mathrm{RH}$-ethylamide on plasma gonadotropin levels and oocyte maturation in adult female coho salmon (Oncorhynchus kisutch). Gen. Comp. Endocrinol., 49: 470-476.

Weil, C., Fostier, A., Horvath, L., Marlot, S. and Berscenyi, M., 1980. Profiles of plasma gonadotropin and $17 \beta$-estradiol in the common carp, Cyprinus carpio L., as related to spawning induced by hypophysation or LH-RH treatment. Reprod. Nutr. Dev,, $20: 1041-1050$.

Yamamoto, K., Nagahama, Y. and Yamazaki, F., 1966. A method to induce artificial spawning of goldfish all through the year. Bull. Jpn. Soc. Sci. Fish., 32: 977-983. 